\title{
Systematic review of community efforts in early handling post- exposure prophylaxis cases of rabies animal bite transmission
}

\author{
Tanti Marjiana $^{1}$, Asti Melani Astari ${ }^{2}$, Lilik Zuhriyah ${ }^{3}$ \\ ${ }^{1,2}$ Department of Nursing, Universitas Brawijaya, Indonesia \\ ${ }^{3}$ Department of Public Health Sciences, Universitas Brawijaya, Indonesia
}

\begin{tabular}{l} 
Article Info \\
\hline Article history: \\
Received Jul 3, 2020 \\
Revised Dec 21, 2020 \\
Accepted Jan 2, 2021 \\
\hline
\end{tabular}

Keywords:

Awareness

Community

Post-exposure prophylaxis

Rabies animal bite wound

\begin{abstract}
Rabies is acute progressive encephalitis, caused by a virus that enters the body after the bite of an infected animal, and migrates to the brain. Management of rabies animal bite transmission (GHPR) with post-exposure prophylaxis (PEP) is the most important strategy for preventing rabiesrelated mortality. GHPR victims need the right PEP. Effective post-exposure provision depends on good individual awareness about rabies and access to health services. To find out the efforts made by the community in raising public awareness to get PEP by doing initial handling after GHPR appropriately. This systematic review begins by identifying the literature on scientific articles that have been published in 2014-2019 in international databases namely Proquest, ScienceDirect, Springer and Ebsco. Selection is done by systematic reviews and meta-analyses (PRISMA) flow diagram and selected using the Joanna Briggs Institute (JBI) checklist format tools. The nine relevant articles were obtained to be analyzed into a systematic review, namely four articles from the Proquest database, two articles from the ScienceDirect database and three articles from the Ebsco database. Community efforts in initial treatment of victims exposed to GHPR are immediately carried out by applying wound washing, providing antiseptics and immediately to health care facilities to get further treatment. The community should understand important information about handling practices in GHPR wound management appropriately. PEP was an immediate action for early relief when victims are exposed to GHPR. PEP was conducted as an effort to prevent the virus from developing into dangerous stages that could result in death.
\end{abstract}

This is an open access article under the CC BY-SA license.

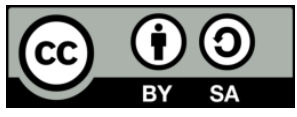

\section{Corresponding Author:}

Tanti Marjiana

Rumah Sakit Umum Daerah Kabupaten Lebong

Ds. Muning Agung, Kec. Lebong Sakti, Kab. Lebong, Prop. Bengkulu, Indonesia

Email: tantimarjiana@gmail.com

\section{INTRODUCTION}

Rabies is acute progressive encephalitis, caused by a virus that enters the body after the bite of an infected animal, and migrates to the brain $[1,2]$. Rabies is caused by a group of antigen-related viruses in the genus Lyssavirus [3]. The rabies virus is transmitted from mammals, by transmission through bites, scratches, blisters or contact with the saliva of infected animals [4]. These mammals are warm-blooded animals that have been infected with rabies can be transmitted through bites [5]. GHPR transmission occurs mainly from dogs (98\%) and then monkeys and cats that have been infected with rabies [6].

Every year countless people in the world are exposed to GHPR, but the highest incidence occurs in developing countries [7]. There is an $95 \%$ incidence of rabies mortality in Africa and Asia from all over the 
world [8]. Rabies prevalence is one death every nine minutes, 95,000 deaths worldwide per year, 40\% are children $[9,10]$. This disease is also rarely reported in the regions because most of the victims died at home. Lack of awareness of rabies can negatively impact rabies prevention and control measures in the community. Low knowledge of rabies results in bad practice and not all GHPR victims seek care in the healthcare sector. Death and loss of economic productivity due to premature death are the most serious effects of canine rabies. The highest mortality rates are in areas with limited dog vaccination, where PEP is the only savior for at-risk populations, but PEP supply and distribution systems are completely inadequate in many areas and are often very expensive [11, 12]. World rabies day was established in 2007 which aims to raise global awareness about rabies and to provide information about preventing rabies. The event is held annually on September 28, with various activities, media outreach and initiatives carried out by individuals, professionals, organizations and governments from local to international levels. To respond to the lack of awareness about appropriate rabies prevention strategies, developing and increasing access to basic awareness and educational resources is an important part [13]. Animal bites often occur in everyday life. Physical trauma from bites of rabiestransmitting animals (GHPR) is an initial trauma that results in soft tissue tearing [14]. The trauma resulting from these bites includes lacerations, avulsions, punctures, scratches and tissue destruction [4]. Damaged tissue will make the wound very vulnerable to infection [15].

Clinical manifestations of rabies can progress to dangerous stages in GHPR victims [16]. Rabies affects the central nervous system with prodromal symptoms such as fever, headaches, and flu, but infections can develop rapidly causing hallucinations, paralysis and ultimately death due to respiratory distress [17]. Management of GHPR with post-exposure prophylaxis (PEP) is the most important strategy for preventing mortality [18]. PEP is an immediate action for GHPR victims in health facilities. This action prevents the entry of the virus into the central nervous system, which then results in rapid death [19]. GHPR victims need the right PEP. Effective administration of post-exposure prophylaxis depends on good individual awareness about rabies, and access to health services [20]. Although PEP is widely available, deaths can occur due to lack of adherence to the recommended treatment guidelines [21]. One of the main problems in preventing rabies at the most basic level is the lack of knowledge among people living in endemic rabies areas [13]. Awareness about rabies and seeking treatment are very important both for preventive measures and disease control [22]. One important requirement for achieving "Zero human rabies death by 2030" is to build awareness of PEP and care for victims exposed to GHPR [23]. The purpose of this systematic review is to find out what is the efforts made by the community in raising public awareness to obtain PEP by conducting initial handling after GHPR appropriately?

\section{RESEARCH METHOD}

The first preparation of this systematic review was determination of time that only took the research from 2014 to 2019. The following preparation was determination of the keywords that were "awareness" AND "animal bite" AND rabies, then determined the source database that was Proquest, ScienDirect, Springer and Ebsco and determined the exclusion and inclusion criteria. The inclusion criteria were rabies animal bite wound, and PEP. While the exclusion criteria are veterinary medicine, rabies history, rabies financing, dog vaccination and dog population. Selection is done by preferred reporting items for systematic reviews and meta-analyses (PRISMA) flow diagram and selected using the Joanna Briggs Institute (JBI) checklist format tools.

\section{RESULTS AND DISCUSSION}

The articles searching conducted by using several keywords, then found the number of search results using keywords: awareness AND PEP AND rabies is 141 articles from the Proquest database, 23 articles from the ScienceDirect database, one article from the Springer database and 59 articles from the Ebsco database. This process is part of identification through the PRISMA framework, then reads the title and abstract of each article, the number of articles entered for the next process based on the title and abstract is 111 from the Proquest database, 19 articles from the ScienceDirect database, one article from the springer database and 12 article from the Ebsco database, this process is a screening of the Preferred Reporting Items for systematic reviews and meta-analyses (PRISMA) framework. Next, download the full text and read each complete text from the article to enter the inclusion and exclusion criteria, and find articles with inclusion criteria, namely rabies animal bite wound and PEP database articles Proquest, ScienDirect and Ebsco, this process is a eligibility process and is included from PRISMA and is an analysing process. This process also uses the Joanna Briggs Institute (JBI) checklist format tools as the article selection process. Furthermore, identifying duplicated articles found 14 articles and nine articles included in the review. PRISMA Flow Chart for Literature Identification as shown in Figure 1. 


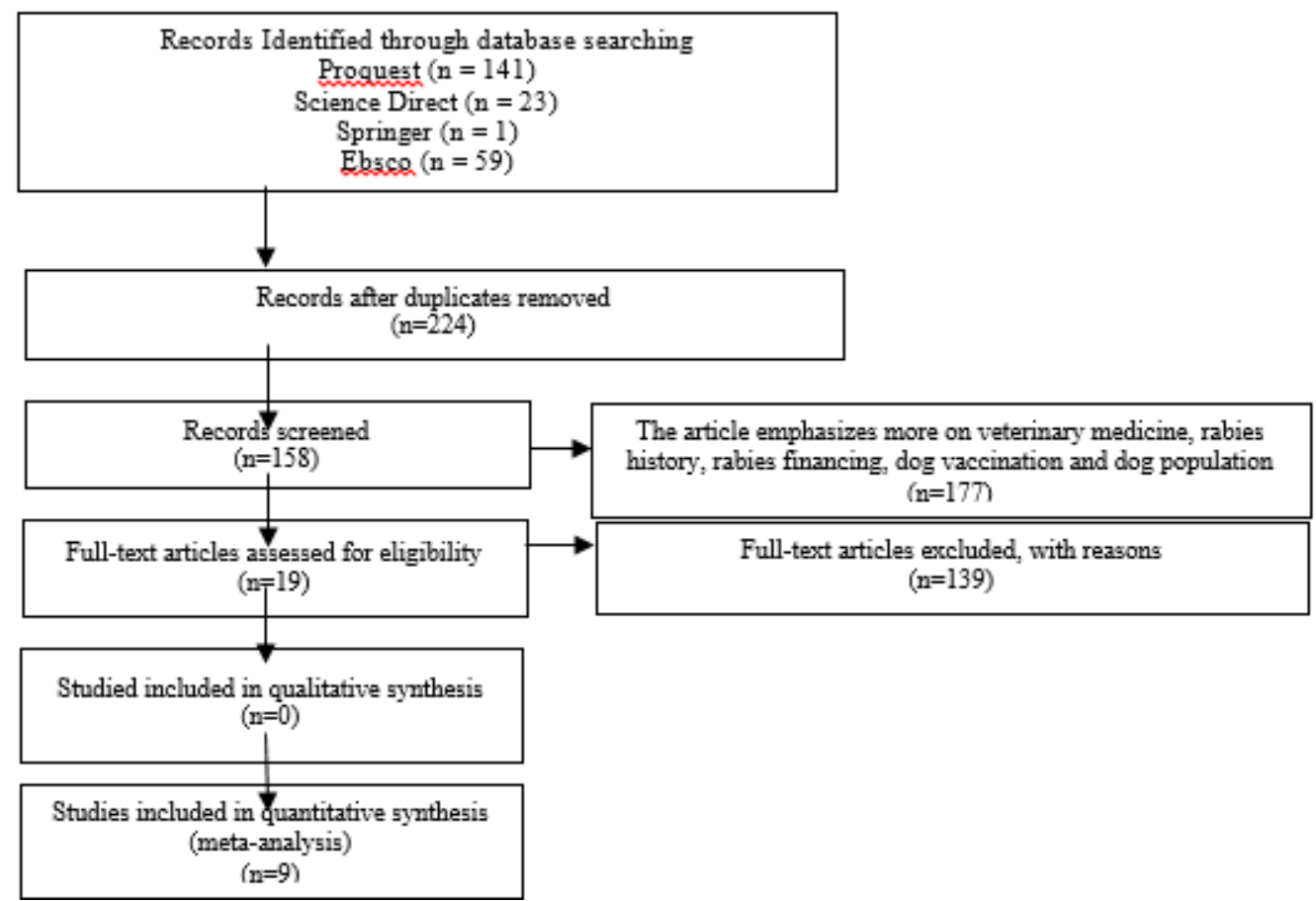

Figure 1. PRISMA flow chart for literature identification

This process is part of identification through the PRISMA framework, then reads the title and abstract of each article, the number of articles entered for the next process based on the title and abstract is 111 from the Proquest database, 19 articles from the ScienceDirect database, one article from the springer database and 12 article from the Ebsco database, this process is a screening of the preferred reporting items for systematic reviews and meta-analyses (PRISMA) framework. Next, download the full text and read each complete text from the article to enter the inclusion and exclusion criteria, and find articles with inclusion criteria, namely rabies animal bite wound and PEP database articles Proquest, ScienDirect and Ebsco, this process is a eligibility process and is included from PRISMA and is an analyzing process. This process also uses the Joanna Briggs Institute (JBI) checklist format tools as the article selection process. Furthermore, identifying duplicated articles found 14 articles and nine articles included in the review. The articles that have been selected could be explained in detail as shown in Table 1 [19, 21, 22, 24-29].

Table 1. Summary of research results on building PEP among victims of GHPR

\begin{tabular}{|c|c|c|c|c|c|c|c|}
\hline $\begin{array}{l}\text { Author } \\
\text { (year) }\end{array}$ & $\begin{array}{l}\text { Level } \\
\text { (JBI) }\end{array}$ & Objective & Methods & Samples & Intervention & $\begin{array}{c}\text { Data } \\
\text { analysis }\end{array}$ & Research results \\
\hline [21] & $4 . c$ & $\begin{array}{l}\text { - Determine } \\
\text { behavior } \\
\text { seeking } \\
\text { treatment for } \\
\text { animal bite } \\
\text { victims and } \\
\text { PEP received } \\
\text { by GHPR } \\
\text { victims. } \\
\text { - Knowing } \\
\text { knowledge } \\
\text { about rabies } \\
\text { prevention. } \\
\text { - Knowing } \\
\text { compliance to } \\
\text { complete the } \\
\text { postexposure } \\
\text { rabies } \\
\text { vaccination } \\
\text { program. }\end{array}$ & $\begin{array}{l}\text { Quantitative } \\
\text { research } \\
\text { methods with } \\
\text { descriptive } \\
\text { research } \\
\text { designs. }\end{array}$ & $\begin{array}{l}529 \text { GHPR } \\
\text { victims in } 18 \\
\text { Indian Health } \\
\text { care facilities. }\end{array}$ & $\begin{array}{l}\text { - Give PEP to } \\
\text { victims of GHPR } \\
\text { according to WHO } \\
\text { recommendations by } \\
\text { medical staff and } \\
\text { starting with the first } \\
\text { dose of anti-rabies } \\
\text { vaccine. } \\
\text { - Follow up on } \\
\text { every drug reaction } \\
\text { starting on days } 3,7 \text {, } \\
\text { 14, and } 28 \text {. } \\
\text { - Inform about the } \\
\text { date of vaccination. } \\
\text {-Record the reasons } \\
\text { for dropping out of } \\
\text { vaccines. }\end{array}$ & $\begin{array}{l}\text { Chi- } \\
\text { square. }\end{array}$ & $\begin{array}{l}\text { The results of the study } \\
\text { said } 64.7 \% \text { of } \\
\text { respondents did } \\
\text { washing wounds and } \\
73.7 \% \text { of respondents } \\
\text { realized they received } \\
\text { PEP on time. }\end{array}$ \\
\hline [22] & 4.b & $\begin{array}{l}\text { Assess the } \\
\text { knowledge, } \\
\text { attitudes and }\end{array}$ & $\begin{array}{l}\text { Quantitative } \\
\text { research } \\
\text { methods with }\end{array}$ & $\begin{array}{l}384 \text { GHPR } \\
\text { victims or } \\
\text { guardians of }\end{array}$ & $\begin{array}{l}\text { The need for } \\
\text { cultural and gender } \\
\text { sensitive awareness }\end{array}$ & $\begin{array}{l}\text { Linear } \\
\text { regression. }\end{array}$ & $\begin{array}{l}\text { The results mentioned } \\
7 \% \text { of respondents } \\
\text { indicated that washing }\end{array}$ \\
\hline
\end{tabular}

Community efforts in early handling post-exposure prophylaxis cases of rabies animal... (Tanti Marjiana) 


\begin{tabular}{|c|c|c|c|c|c|c|c|}
\hline [24] & 4.b & $\begin{array}{l}\text { - Assess } \\
\text { awareness of } \\
\text { rabies as an } \\
\text { infectious } \\
\text { disease and its } \\
\text { prevention. } \\
\text { - Asses } \\
\text { perceived health } \\
\text { risks associated } \\
\text { with GHPR }\end{array}$ & $\begin{array}{l}\text { Quantitative } \\
\text { research } \\
\text { methods with } \\
\text { a cross- } \\
\text { sectional } \\
\text { study design. }\end{array}$ & $\begin{array}{l}\text { underage } \\
\text { cases (aged } \\
<15 \text { years) at } \\
\text { the Jimma } \\
\text { Town health } \\
\text { center, } \\
\text { Ethiopia. } \\
1,012 \\
\text { household } \\
\text { participants in } \\
\text { India. }\end{array}$ & $\begin{array}{l}\text { Identify knowledge } \\
\text { gaps, cultural } \\
\text { beliefs, and } \\
\text { behavior patterns } \\
\text { that can cause } \\
\text { obstacles to } \\
\text { controlling disease. }\end{array}$ & $\begin{array}{l}\text { Logistic } \\
\text { regression. }\end{array}$ & $\begin{array}{l}\text { The results of the study } \\
\text { said } 22.9 \% \text { of } \\
\text { respondents said } \\
\text { washing their wounds } \\
\text { with water and soap } \\
\text { when exposed to } \\
\text { GHPR, } 5.7 \% \text { of } \\
\text { respondents had told } \\
\text { that they would apply } \\
\text { the drug traditional. } \\
63.5 \% \text { of respondents } \\
\text { said they would } \\
\text { actively. }\end{array}$ \\
\hline [25] & 4.b & $\begin{array}{l}\text { Assess the } \\
\text { knowledge, } \\
\text { attitudes and } \\
\text { practices of the } \\
\text { rural general } \\
\text { population } \\
\text { against rabies. }\end{array}$ & $\begin{array}{l}\text { Quantitative } \\
\text { research } \\
\text { methods with } \\
\text { a cross- } \\
\text { sectional } \\
\text { study design. }\end{array}$ & $\begin{array}{l}127 \text { residents } \\
\text { in Shirsuphal } \\
\text { Village, India. }\end{array}$ & $\begin{array}{l}\text { Efforts to reduce } \\
\text { the incidence of } \\
\text { GHPR. }\end{array}$ & $\begin{array}{l}\text { Logistic } \\
\text { regression. }\end{array}$ & $\begin{array}{l}\text { The results of the study } \\
\text { said } 73 \% \text { of } \\
\text { respondents knew that } \\
\text { rabies could be } \\
\text { prevented by giving } \\
\text { PEP to GHPR victims. }\end{array}$ \\
\hline & & & & & & & $\begin{array}{l}87 \% \text { of respondents. } \\
\text { Be aware of the } \\
\text { ineffectiveness of } \\
\text { traditional medicine } \\
\text { applications, such as } \\
\text { Chili powder / } \\
\text { turmeric. } 42 \% \text { of } \\
\text { respondents. }\end{array}$ \\
\hline [26] & 2.d & $\begin{array}{l}\text { Understand the } \\
\text { characteristics } \\
\text { associated with } \\
\text { adherence to } \\
\text { vaccine } \\
\text { regimens and } \\
\text { RIG. }\end{array}$ & $\begin{array}{l}\text { Quantitative } \\
\text { research } \\
\text { methods with } \\
\text { a } \\
\text { retrospective } \\
\text { research } \\
\text { design. }\end{array}$ & $\begin{array}{l}14,296 \\
\text { patients in } \\
\text { Vietnam. }\end{array}$ & $\begin{array}{l}\text { Perform wound, } \\
\text { vaccine and rabies } \\
\text { immunoglobulin } \\
\text { (RIG) treatments. }\end{array}$ & $\begin{array}{l}\text { Logistic } \\
\text { regression. }\end{array}$ & $\begin{array}{l}\text { The results said } 41.4 \% \\
\text { of patients completed } \\
\text { five-dose } \\
\text { intramuscular (IM) } \\
\text { injections and } 81.6 \% \\
\text { of patients completed } \\
\text { eight-dose intradermal } \\
\text { (ID) injections. } 26 \% \text { of } \\
\text { patients received RIG. }\end{array}$ \\
\hline [27] & 4.b & $\begin{array}{l}\text { Investigate } \\
\text { Knowledge, } \\
\text { Attitudes and } \\
\text { Practices in } \\
\text { Rabies. }\end{array}$ & $\begin{array}{l}\text { Quantitative } \\
\text { research } \\
\text { methods by } \\
\text { design Cross- } \\
\text { sectional } \\
\text { research. }\end{array}$ & $\begin{array}{l}434 \text { people in } \\
\text { Pakistan. }\end{array}$ & $\begin{array}{l}\text { Providing } \\
\text { knowledge to the } \\
\text { layman for } \\
\text { management and } \\
\text { effective rabies } \\
\text { prevention. }\end{array}$ & $\begin{array}{l}\text { Logistic } \\
\text { regression. }\end{array}$ & $\begin{array}{l}\text { The results of the study } \\
\text { said } 77.6 \% \text { of } \\
\text { respondents considered } \\
\text { that animal vaccination } \\
\text { important for rabies } \\
\text { prevention. } 39.8 \% \text { of } \\
\text { respondents actively } \\
\text { sought medical } \\
\text { treatment in a hospital } \\
\text { when exposed to } \\
\text { GHPR. }\end{array}$ \\
\hline [28] & 4.b & $\begin{array}{l}\text { Describes post- } \\
\text { GHPR care } \\
\text { seeking } \\
\text { behavior. }\end{array}$ & $\begin{array}{l}\text { Quantitative } \\
\text { research } \\
\text { methods with } \\
\text { a cross- } \\
\text { sectonal }\end{array}$ & $\begin{array}{l}208 \\
\text { households in } \\
\text { Cameron }\end{array}$ & $\begin{array}{l}\text { - Apply knowledge } \\
\text { of attitudes and } \\
\text { practices of GHPR } \\
\text { exposure. } \\
\text { - National efforts to } \\
\text { prevent rabies. }\end{array}$ & $\begin{array}{l}\text { 2-tailed } \\
\text { Fisher } \\
\text { exact test. }\end{array}$ & $\begin{array}{l}\text { The results of the study } \\
\text { mentioned } 6 \% \text { of } \\
\text { respondents indicated } \\
\text { they would wash their } \\
\text { wounds, } 36.7 \% \text { of } \\
\text { respondents indicated } \\
\text { they would call a } \\
\text { doctor, and } 52.6 \% \text { of } \\
\text { respondents reported } \\
\text { that they would seek } \\
\text { medical care. } 3.1 \% \text { of } \\
\text { respondents indicated } \\
\text { that they would seek } \\
\text { PEP, and } 97 \% \text { of } \\
\text { respondents will } \\
\text { consult with traditional } \\
\text { healers. }\end{array}$ \\
\hline [19] & 4.b & Investigate the & Quantitative & 1,015 GHPR & Prioritizing & Logistic & The results of the study \\
\hline
\end{tabular}




\begin{tabular}{|c|c|c|c|c|c|c|c|}
\hline & & $\begin{array}{l}\text { prevalence and } \\
\text { factors that } \\
\text { influence } \\
\text { improper wound } \\
\text { care and the } \\
\text { delay in PEP } \\
\text { after GHPR. }\end{array}$ & $\begin{array}{l}\text { research } \\
\text { methods with } \\
\text { a cross- } \\
\text { sectional } \\
\text { study design. }\end{array}$ & $\begin{array}{l}\text { victims in } \\
\text { Chinese rabies } \\
\text { preventive } \\
\text { clinics. }\end{array}$ & $\begin{array}{l}\text { awareness raising } \\
\text { to prevent rabies } \\
\text { with the right PEP. }\end{array}$ & regression. & $\begin{array}{l}\text { said } 81.2 \% \text { of } \\
\text { respondents from } \\
\text { animal bite victims } \\
\text { treated their injuries } \\
\text { improperly after } \\
\text { GHPR, and } 35.3 \% \text { of } \\
\text { respondents delayed } \\
\text { the initiation of PEP. }\end{array}$ \\
\hline [29] & 4.b & $\begin{array}{l}\text { - Identify the } \\
\text { level of } \\
\text { awareness and } \\
\text { knowledge } \\
\text { about GHPR } \\
\text { wound } \\
\text { management. } \\
\text { - Ensure first aid } \\
\text { measures } \\
\text { adopted by } \\
\text { GHPR victims. } \\
\text { - Knowing } \\
\text { public } \\
\text { awareness about } \\
\text { anti-rabies } \\
\text { vaccines and the } \\
\text { use of health } \\
\text { services. }\end{array}$ & $\begin{array}{l}\text { Quantitative } \\
\text { research } \\
\text { methods with } \\
\text { a cross- } \\
\text { sectional } \\
\text { study design. }\end{array}$ & $\begin{array}{l}250 \text { victims of } \\
\text { GHPR at the } \\
\text { Muradnagar } \\
\text { health care } \\
\text { center. }\end{array}$ & $\begin{array}{l}\text { Local care of the } \\
\text { wound immediately } \\
\text { after the bite is an } \\
\text { important step in } \\
\text { GHPR } \\
\text { management. }\end{array}$ & $\begin{array}{l}\text { Logistic } \\
\text { regression. }\end{array}$ & $\begin{array}{l}\text { The results of the study } \\
\text { said } 80 \% \text { of } \\
\text { respondents had } \\
\text { applied cold paste and } \\
\text { oil to the wound before } \\
\text { coming to the Public } \\
\text { Health Center. } 0.8 \% \\
\text { wash the wound with } \\
\text { soap and water as } \\
\text { initial management at } \\
\text { home, } 16 \% \text { of } \\
\text { respondents do not } \\
\text { take initial } \\
\text { management actions at } \\
\text { home. }\end{array}$ \\
\hline
\end{tabular}

PEP failure can occur in cases of GHPR. The most common causes of PEP failure are (1) lack of use of rabies immunoglobulin (RIG), (2) not all wounds were injected with immunoglobulins, (3) delaying prophylaxis for 6 days, (4) suturing the wound before injection immunoglobulin, and (5) wounds in highly innervated areas of the body such as the face and hands [30]. To avoid failure of PEP, administration of PEP is initiated immediately after GHPR or contact saliva with non-intact skin or mucous membranes if the animal is known or suspected of rabies [31]. Initial treatment for victims exposed to GHPR is carried out immediately before the victim is taken to a health care facility. According to the Ministry of Health of Republic of Indonesia [6] the treatment is carried out by applying wound washing with soap/detergent and running water for 10-15 minutes and providing antiseptics such as povidone iodine, $70 \%$ alcohol in the wound. Research by Haradanhalli et al. [21] in India said $64.7 \%$ of respondents did washing wounds and $73.7 \%$ of respondents realized that they received PEP on time. The research of Tiwari, Robertson, O'dea and Vanak [25] in India said that $73 \%$ of respondents knew that rabies could be prevented by giving PEP to victims of GHPR and $87 \%$ of respondents were aware of the ineffectiveness of traditional medicine applications, such as chili/turmeric powder. According to Liu et al. [19] these actions serve to prevent the entry of the virus into the central nervous system, resulting in rapid mortality in victims. Rabies can be prevented by giving PEP immediately to victims of GHPR [32]. PEP is carried out when GHPR victims arrive at a health facility so that further treatment is appropriate, these actions consist of: extensive wound washing and local wound care immediately after exposure; strong and effective rabies vaccination that meets WHO standards; and administration of RIG if indicated. Proper wound handling and post-exposure rabies vaccination are essential for rabies preventive treatment [19].

Research from Tiwari, Robertson, O'Dea and Vanak [25] also said 97\% of respondents would recommend that GHPR victims be referred to hospitals. Proper wound management after GHPR in a health care facility has the main principle, which includes wound care and appropriate antimicrobial prophylaxis if indicated. Irrigation the wound is important to reduce the rate of subsequent infections. Wound closure is generally not recommended by the guidelines except for facial injuries. Antimicrobial prophylaxis is given for up to five days, which has been recommended by guidelines for the regulation of animal bites in the presence of primary wound closure, moderate to severe injuries, lesions on the hands or face [4]. WHO [33] recommends two main vaccination strategies for prevention of rabies in humans, namely: post-exposure prophylaxis (PEP) which includes extensive and comprehensive washing of wounds at the site of exposure, together with rabies immunoglobulin (RIG) if indicated and administration of a series of vaccines rabies dose. Then pre-exposure (PrEP) is the administration of several doses of rabies vaccine before exposure. Indications and procedures for PEP depend on the type of contact with suspected rabies animals and the victim's vaccination status [33]. The community is necessary to understand that immediate handling is taken after being exposed to GHPR and subsequent actions obtained at health care facilities (public health centre/hospitals/rabies centres). GHPR exposure categories are grouped into three categories. The handling of GHPR victims is based on the exposure group, which has never been vaccinated or vice versa. The recommended immediate PEP for rabies infection can be seen in Table 2. 
Table 2. PEP immediately recommended for exposure to rabies

\begin{tabular}{|c|c|}
\hline Category of exposure to animals carrying rabies & Post-exposure steps \\
\hline \multicolumn{2}{|c|}{ Individuals for all age groups who have not been exposed to pre-exposure vaccines (PrEP) } \\
\hline $\begin{array}{l}\text { Category I } \\
\text { Touch or feed animals, lick intact skin (without exposure) }\end{array}$ & No PEP required \\
\hline $\begin{array}{l}\text { Category II } \\
\text { Biting the skin, small scratches or blisters without bleeding }\end{array}$ & $\begin{array}{l}\text { Immediate wound washing and vaccination: } \\
\text { ID } 2 \text { locations on days } 0,3 \text { and } 7 \\
\text { or } 1 \text { IM location on days } 0,3,7 \text { and between days } 14-28 \text { or } 2 \\
\text { IM locations on day } 0 \text { and } 1 \text { IM location on days } 7,21 \text {. } \\
\text { RIG is not indicated. }\end{array}$ \\
\hline $\begin{array}{l}\text { Category III } \\
\text { Single or multiple transdermal bites or scratches, licked on damaged } \\
\text { skin; } \\
\text { Contamination of mucous membranes with saliva from licking. }\end{array}$ & $\begin{array}{l}\text { Immediate wound washing and vaccination: } \\
\text { ID } 2 \text { locations on days } 0,3 \text { and } 7 \\
\text { or } 1 \text { IM location on days } 0,3,7 \text { and between days } 14-28 \text { or } 2 \\
\text { IM locations on day } 0 \text { and } 1 \text { IM location on days } 7,21 \\
\text { RIG is recommended. }\end{array}$ \\
\hline $\begin{array}{l}\text { Contamination of mucous membranes with saliva from licking. } \\
\qquad \text { Individuals of all age groups } \mathrm{p}\end{array}$ & $\begin{array}{l}1 \mathrm{IM} \text { location on days } 0,3,7 \text { and between days } 14-28 \text { or } 2 \mathrm{IM} \\
\text { locations on day } 0 \text { and } 1 \mathrm{IM} \text { location on days } 7,21 \\
\text { RIG is recommended. } \\
\text { sposure vaccines (PrEP) }\end{array}$ \\
\hline $\begin{array}{l}\text { Category I } \\
\text { Touch or feed animals, lick intact skin (without exposure) }\end{array}$ & No PEP required \\
\hline $\begin{array}{l}\text { Category II } \\
\text { Biting the skin, small scratches or blisters without bleeding }\end{array}$ & $\begin{array}{l}\text { Immediate wound washing and vaccination: } \\
\text { ID } 1 \text { location on days } 0 \text { and } 3 \\
\text { or ID } 4 \text { locations on day } 0 \\
\text { or IM } 1 \text { location on days } 0 \text { and } 3 \\
\text { RIG is not indicated. }\end{array}$ \\
\hline $\begin{array}{l}\text { Category III } \\
\text { Single or multiple transdermal bites or scratches, licked on damaged } \\
\text { skin; contamination of mucous membranes with saliva from licking. }\end{array}$ & $\begin{array}{l}\text { Immediate wound washing and vaccination: } \\
\text { ID } 1 \text { location on days } 0 \text { and } 3 \\
\text { or ID } 4 \text { locations on day } 0 \\
\text { or IM } 1 \text { location on days } 0 \text { and } 3 \\
\text { RIG is not indicated. }\end{array}$ \\
\hline
\end{tabular}

ID (intradermal); IM (intramuscular) [33, 34].

Public knowledge about rabies in general is reflected in community practices and health seeking behavior [12]. It is important for the community to have knowledge, awareness and practices related to GHPR to understand their preparedness in early handling. After they carry out the next initial treatment in a health facility, health workers will respond quickly to continue PEP which prevents death in victims through the provision of PrEP and RIG immediately [35]. Rabies vaccination is an important step to improve public health [36]. The vaccine regimen given for rabies PEP is almost $100 \%$ effective [37]. The rabies vaccine stimulates the immune system to produce antibodies to protect the body from an imminent infection. Therefore, completing the vaccine schedule is very important in ensuring sufficient antibody titers to neutralize the rabies virus and prevent active rabies infection in GHPR victims. Thus, those who did not complete the full PEP schedule were less likely to produce protective titers of antibodies to prevent infection [38]. In cases of category III exposure, RIG is also recommended in addition to wound care and PEP vaccination [38]. Regardless of the availability of RIG, all patients exposed to category III should receive the rabies vaccine immediately. RIG should be given only once, preferably together when starting PEP and no later than 7 days after the first rabies vaccine [36]. Very few people have the right awareness in implementing PEP. The results of Jain and Jain research [29] in India said 80\% of GHPR victims applied cold paste and oil before coming to primary care; research result. Kabeta et al. [22] in Ethiopia mentioned that $43 \%$ of victims of GHPR did not take initial treatment after GHPR. This finding highlights the lack of understanding of early treatment that is important for preventing infection. The availability of PEP at the Center, but the lack of awareness by the public about preventive measures that hamper seeking immediate medical assistance $[39,40]$.

Some people are still looking for help or treatment outside health service facilities. In line with the research conducted by Costa et al. [28] in Cameroon stated that 9.7\% of respondents would consult traditional healers in handling the GHPR case. Masthi, Sanjay, Pradeep and Anwith [24] in India said that $5.7 \%$ of respondents would apply traditional medicine after GHPR exposure. These findings indicate that increased knowledge about preventive measures in rabies that may not have an impact on the search for health services if the cost of medical care is an obstacle for the community to get further treatment [28]. Physical trauma from GHPR is an initial injury resulting in soft tissue tearing [14]. The presence of damaged tissue makes the wound very vulnerable to infection [15]. The rabies virus that is exposed from animals enters the body after a bite can then migrate to the brain [1]. If the initial treatment has been done improperly, signs and symptoms of rabies can develop into dangerous stages [16]. The main factors found in the community influence knowledge and practice in handling GHPR. These factors include socioeconomic status 
and education. The greatest risk of exposure to rabies is likely to occur in vulnerable communities, especially in the poor, with low or no formal education levels, insufficient supply of vaccines and RIG to government hospitals, the distance from where GHPR victims live to government hospitals may be causes of low vaccine coverage among GHPR victims [41, 42]. A study by Liu et al. [19] in China mentioned that 35.3\% of GHPR victims delayed the initiation of PEP. The main reason for non-compliance to resolve anti-rabies vaccination according to Shivasakthimani, Ravivarman, and Murali [43] is socio-economic factors; such as lost wages, unreachable distance to health facilities, high costs, coinciding with school time, forgotten dates and unavailability of vaccines in health care facilities. The economic burden associated with financing can be reduced through more prudent and cost-effective administration. The method developed describes an important gap in knowledge, providing an initial picture of the distribution of the rabies burden according to local country policies on rabies control and prevention measures. Improved surveillance and reporting of GHPR cases is needed, both for better cost estimates, to monitor the impact of control efforts [11]. Through the investment of GAVI (a not-for-profit organization and vaccine alliance) PEP can be made free during treatment, this will avoid financial constraints on individuals and governments, and also convince vaccine suppliers operating in low- and middle-income countries. In addition, Gavi's investment could bring health system benefits such as increased capacity for monitoring GHPR exposure, mortality, and responsible use of PEP [44]. It is also hoped that a sustainable and strategic health program from health professionals, government and non-government organizations to control and prevent disease and secure a rabies-free zone [45].

Education about the danger of rabies is important to be carried out in the local community as an effort to overcome it. Community education is an important strategy in preventing rabies in humans. According to Dilago and Nash [46, 47] material that can be delivered in community activities includes: transmission of rabies, initial help after GHPR, and efforts to prevent rabies. To make it easier for the public to understand the material presented in the outreach activities, health education materials can be complemented by video playback, and use of image media to make it more interesting and to report to government agencies when they see a dog suspected of rabies in the community. This activity will help improve the search for PEP and the compliance behavior of people exposed to rabies infection from animals [48]. School health programs that include primary-level students ensure that these efforts reach them. It is also important to emphasize avoiding exposure and promoting wound cleaning and visiting health care after exposure [49]. Rabies related training is important to be carried out by nursing staff. The treatment of injuries to victims of GHPR is the treatment of injuries that are different from other injuries. According to Nash [47] nurses attending training have the aim to increase the knowledge and skills needed by nurses working in the community. Thus, nurses as health workers are expected to have special skills. The government is a higher authority that has an important role in providing support to facilitate facilities and infrastructure as well as coordinating the institutions. According to $\mathrm{Ki}$ and Maria [50] the provision of adequate resources and the provision of facilities and infrastructure is the main responsibility of the health institution. Coordination is important to do with the local Animal Husbandry Service as a rabies-transmitted animal management system by vaccinating, eliminating, and limiting the traffic of rabies-transmitting animals. A greater focus on mass dog vaccinations could eliminate disease at its source, reduce the need for costly PEP and prevent major deaths in communities at risk [11].

\section{CONCLUSION}

Public awareness about rabies and treatment-seeking behaviour are highly prioritized in disease prevention and control. Initial handling of GHPR is an important action to be taken immediately in the community. But it is still found in the community that the wound was washed improperly, using traditional medicines on GHPR wounds and visiting traditional healers. The community needs to get important information on appropriate handling practices in GHPR wound management. PEP is an immediate action for early relief when victims are exposed to GHPR. PEP is conducted as an effort to prevent the virus from developing into dangerous stages that can result in death. The action is carried out by applying wound washing with soap or detergent with running water for 5-15 minutes and giving antiseptics such as povidone iodine, $70 \%$ alcohol in the wound. GHPR victims must be immediately referred to health care facilities (public health centre/hospitals/rabies centres) to get further action. It should also emphasize primary school students to avoid exposure and promote wound cleaning and health care use after GHPR. Furthermore, reducing the risk of rabies in humans should include increasing community resources for primary prevention by routine pet vaccination and PrEP for people at high risk of exposure. 


\section{REFERENCES}

[1] S. Welburn, I. Beange, M. Ducrotoy, and A. Okello, "The neglected zoonoses-the case for integrated control and advocacy," Clinical Microbiology and Infection, vol. 21, no. 5, pp. 433-443, 2015.

[2] N. R. Masthi, B. Pradeep, and G. Bilagumba, "A multicentric community survey on animal exposures among humans in India," Indian Journal of Public Health, vol. 63, no. 5, pp. 9, 2019.

[3] D. Middleton, K. Johnson, R. Rosatte, J. Hobbs, S. Moore, L. Rosella, et al., "Human rabies post-exposure prophylaxis and animal rabies in Ontario, Canada, 2001-2012," Zoonoses and Public Health, vol. 62, no. 5, pp. 356-364, 2015.

[4] M. P. Cheng, L. O. Parkes, K. Paquette, C. P. Yansouni, and T. C. Lee, "River otter bite in a 52-year-old woman: managing animal bites," CMAJ, vol. 188, no. 17, pp. E513-E516, 2016.

[5] K. K. Jani and N. Gupta, "Rabies and management of animal bites," Indian Journal of Medical Sciences, vol. 68, pp. 13-16, 2016.

[6] Ministry of Health, Center for data and information from the Ministry of Health of the Republic of Indonesia on rabies situation and analysis /Pusat data dan informasi Kementerian Kesehatan RI situasi dan analisis rabies, 2014. [Online]. Available: https://pusdatin.kemkes.go.id/resources/download/pusdatin/infodatin/infodatin-rabies.pdf

[7] B. Devleesschauwer, A. Aryal, B. K. Sharma, A. Ale, A. Declercq, S. Depraz, et al., "Epidemiology, impact and control of rabies in Nepal: a systematic review," PLoS Neglected Tropical Diseases, vol. 10, no. 2, pp. e0004461, 2016.

[8] WHO, Rabies, 2020. [Online]. Available: https://www.who.int/news-room/fact-sheets/detail/rabies

[9] WHO, FAO, OIE, and GARC, "United Against Rabies Collaboration First annual progress report: global strategic plan to end human deaths fromdog-mediated rabies by 2030," Jeneva: WHO Press, 2019.

[10] M. Samanta, R. Mondal, A. Shah, A. Hazra, S. Ray, G. Dhar, et al., "Animal bites and rabies prophylaxis in rural children: Indian perspective," Journal of Tropical Pediatrics, vol. 62, no. 1, pp. 55-62, 2016.

[11] K. Hampson, L. Coudeville, T. Lembo, M. Sambo, A. Kieffer, M. Attlan, et al., "Estimating the global burden of endemic canine rabies," PLoS Neglected Tropical Diseases, vol. 9, no. 4, pp. e0003709, 2015.

[12] C. Mbilo, J.-B. Kabongo, P. P. Pyana, L. Nlonda, R. W. Nzita, B. Luntadila, et al., "Dog ecology, bite incidence, and disease awareness: a cross-sectional survey among a rabies-affected community in the Democratic Republic of the Congo," Vaccines, vol. 7, no. 3, pp. 98, 2019.

[13] D. Balaram, L. H. Taylor, K. A. Doyle, E. Davidson, and L. H. Nel, "World Rabies Day-a decade of raising awareness," Tropical Diseases, Travel Medicine and Vaccines, vol. 2, p. 19, 2016.

[14] K. Maniscalco and M. A. Edens, "Bites, Animal," in StatPearls [Internet], ed: StatPearls Publishing, 2018.

[15] W. Lin and P. M. Patil, "Facial dog attack injuries," Indian Journal of Surgery, vol. 77, no. 1, pp. 55-58, 2015.

[16] J. Skeet, "Best practice: Rabies vaccination and post-exposure prophylaxis," Hospital, vol. 6, pp. 08, 2019.

[17] P. Khandelwal, N. Hajira, and S. Dubey, "Management of maxillofacial injuries in humans due to animal bites and mauling: A report of three cases," Nigerian Postgraduate Medical Journal, vol. 22, no. 4, pp. 241-244, 2015.

[18] H. Salve, S. Kumar, S. Rizwan, et al., "Feasibility of sustainable provision of intradermal post exposure prophylaxis against rabies at primary care level-evidence from rural Haryana," BMC Health Services Research, vol. 14, p. 278, 2014.

[19] Q. Liu, X. Wang, B. Liu, et al., "Improper wound treatment and delay of rabies post-exposure prophylaxis of animal bite victims in China: Prevalence and determinants," PLoS Neglected Tropical Diseases, vol. 11, no. 7, pp. 1-14, 2017, doi: https://doi.org/10.1371/journal.pntd.0005663.

[20] K. LeRoux, D. Stewart, K. Perrett, L. H. Nel, J. Kessels, and B. Abela-Ridder, "Rabies control in KwaZulu-Natal, South Africa," Bulletin of The World Health Organization, vol. 96, no. 5, pp. 360-365, 2018.

[21] R. S. Haradanhalli, H. S. Anwith, B. S. Pradeep, S. Isloor, and G. Bilagumba, "Health-seeking behavior and compliance to post exposure prophylaxis among animal bite victims in India," Indian Journal of Public Health, vol. 63, no. Supplement, p. 20, 2019.

[22] T. Kabeta, B. Deresa, W. Tigre, et al., "Knowledge, attitudes and practices of animal bite victims attending an antirabies health center in Jimma Town, Ethiopia," PLoS Neglected Tropical Diseases, vol. 9, no. 6, pp. 1-14, 2015.

[23] A. C. Jidge, H. G. Rokade, and S. K. Mangulikar, "Knowledge, attitude and practices about rabies prophylaxis among medical officers," International Journal Of Community Medicine and Public Health, vol. 6, no. 5, pp. 19601964, 2019.

[24] N. R. Masthi, T. Sanjay, S. Pradeep, and H. Anwith, "Community awareness and risk of rabies associated with exposure to animals in India," Indian Journal of Public Health, vol. 63, no. 5, pp. 15-19, 2019.

[25] H. K. Tiwari, I. D. Robertson, M. O’Dea, and A. T. Vanak, "Knowledge, attitudes and practices (KAP) towards rabies and free roaming dogs (FRD) in Panchkula district of north India: A cross-sectional study of urban residents," PLoS Neglected Tropical Diseases, vol. 13, no. 4, pp. 1-14, pp. 1-17, 2019, doi: 10.1371/journal.pntd.0007384 .

[26] C. H. Tran, D. O. Afriyie, T. N. Pham, et al., "Rabies post-exposure prophylaxis initiation and adherence among patients in Vietnam, 2014-2016," Vaccine, no. Supplement 1, pp. A54-A63, 2019.

[27] A. Khan, R. Ayaz, A. Mehtab, et al., "Knowledge, attitude \& practices (KAPs) regarding rabies endemicity among the community members, Pakistan," Acta Tropica, vol. 200, pp. 105156, 2019.

[28] G. B. Costa, A. Gilbert, B. Monroe, et al., "The influence of poverty and rabies knowledge on healthcare seeking behaviors and dog ownership, Cameroon," PloS One, vol. 13, no. 6, pp. 197330, 2018, doi: 10.1371/journal.pone.0197330. 
[29] P. Jain and G. Jain, "Study of general awareness, attitude, behavior, and practice study on dog bites and its management in the context of prevention of rabies among the victims of dog bite attending the OPD services of CHC Muradnagar," Journal of Family Medicine and Primary Care, vol. 3, no. 4, pp. 355-8, 2014.

[30] M. Nadeem and P. K. Panda, "Survival in human rabies but left against medical advice and death followedCommunity education is the need of the hour," Journal of Family Medicine and Primary Care, vol. 9, no. 3, pp. 1736-1740, 2020.

[31] S. W. Audu, P. P. Mshelbwala, B. M. Jahun, et al., "Two fatal cases of rabies in humans who did not receive rabies postexposure prophylaxis in Nigeria," Clinical Case Reports, vol. 7, no. 4, pp. 749-752, 2019.

[32] J. Changalucha, R. Steenson, E. Grieve, et al., "The need to improve access to rabies post-exposure vaccines: Lessons from Tanzania," Vaccine, vol. 37, no. Suppl 1, pp. A45-A53, 2019.

[33] WHO, "Rabies vaccines: WHO position paper, April 2018-recommendations," Vaccine, vol. 36, pp. 5500-5503, 2018.

[34] S. Yan, Y. Chen, W. Ye, F. Chen, and L. Li, "Characteristics and factors associated with post-exposure prophylaxis (PEP) treatment of dog and cat bites among left-behind children: a cross-sectional study in two cities of China," BMJ Open, vol. 9, no. 5, pp. 1-7, 2019, doi: 10.1136/bmjopen-2018-024764.

[35] T. Tenzin, J. Namgyal, and S. Letho, "Community-based survey during rabies outbreaks in Rangjung town, Trashigang, eastern Bhutan, 2016," BMC Infectious Diseases, vol. 17, no. 1, p. 281, 2017.

[36] K. L. O'Brien and T. Nolan, "The WHO position on rabies immunization-2018 updates," Vaccine, vol. 37, p. A85, 2019.

[37] A. Tarantola, M. C. Tejiokem, and D. J. Briggs, "Evaluating new rabies post-exposure prophylaxis (PEP) regimens or vaccines," Vaccine, vol. 37, pp. A88-A93, 2019.

[38] C. Guo, Y. Li, Y. Huai, et al., "Exposure history, post-exposure prophylaxis use, and clinical characteristics of human rabies cases in China, 2006-2012," Scientific Reports, vol. 8, no. 1, pp. 1-10, 2018.

[39] A. Ganasva, B. Bariya, M. Modi, and K. Shringarpure, "Perceptions and treatment seeking behaviour of dog bite patients attending regional tertiary care hospital of central Gujarat, India," J Res Med Den Sci, vol. 3, no. 1, pp. 60-4, 2015.

[40] T. Hemachudha, G. Ugolini, S. Wacharapluesadee, et al., "Human rabies: neuropathogenesis, diagnosis, and management," The Lancet Neurology, vol. 12, no. 5, pp. 498-513, 2013.

[41] M. Sambo, T. Lembo, S. Cleaveland, et al., "Knowledge, attitudes and practices (KAP) about rabies prevention and control: a community survey in Tanzania," PLoS Neglected Tropical Diseases, vol. 8, no. 12, p. 3310, 2014.

[42] S. Ghosh, S. Chowdhury, N. Haider, et al., "Awareness of rabies and response to dog bites in a Bangladesh community," Veterinary Medicine and Science, vol. 2, no. 3, pp. 161-169, 2016.

[43] R. Shivasakthimani, G. Ravivarman, and R. Murali, "Compliance of anti-rabies vaccine among dog bite victims in an urban slum of Chennai: a cross sectional study," International Journal Of Community Medicine And Public Health, vol. 5, no. 4, pp. 1487-1491, 2018.

[44] D. Wentworth, K. Hampson, S. M. Thumbi, et al., "A social justice perspective on access to human rabies vaccines," Vaccine, vol. 37, pp. A3-A5, 2019.

[45] A. K. Gebremeskel, B. M. Tanga, A. Getachew, and Y. Eshetu, "Assessment of public knowledge, attitude and practices towards rabies in the community of Kombolcha, Southern Wollo, Amhara Reginal State, Ethiopia," Journal of Public Health and Epidemiology, vol. 11, no. 1, pp. 38-48, 2019.

[46] Z. Dilago, "counseling and implementation of rabies vaccination in Tagalaya Village, Tobelo District/Penyuluhan dan pelaksanaan vaksinasi rabies di Desa Tagalaya Kecamatan Tobelo," Jurnal Pengabdian Masyarakat: Darma Bakti Teuku Umar, vol. 1, no. 1, pp. 93-100, 2019.

[47] T. J. Nash, "Unveiling the truth about nurses' personal preparedness for disaster response: A pilot study," Medsurg Nursing, vol. 24, no. 6, pp. 425-31, 2015.

[48] K. Penjor, T. Tenzin, and R. K. Jamtsho, "Determinants of health seeking behavior of animal bite victims in rabies endemic South Bhutan: a community-based contact-tracing survey," BMC Public Health, vol. 19, no.1, pp. 237, 2019.

[49] D. Moran, P. Juliao, D. Alvarez, et al., "Knowledge, attitudes and practices regarding rabies and exposure to bats in two rural communities in Guatemala," BMC research notes, vol. 8, no. 955, pp. 1-7, 2015, doi: 10.1186/s13104014-0955-1.

[50] L. K. Ki and H. S. Y. Maria, "Perceptions of emergency nurses during the human swine influenza outbreak: A qualitative study," International Emergency Nursing, vol. 21, no. 4, pp. 240-246, 2013, doi: 10.1016/j.ienj.2012.08.008. 